\title{
UJI VALIDITAS MODUL MEDIA PEMBELAJARAN BUSY BOX SEX EDUCATION UNTUK MENINGKATKAN PENGETAHUAN PENDIDIKAN SEKSUAL DI SLB HARAPAN MULIA KOTA JAMBI
}

\section{VALIDITY TEST OF THE BUSY BOX SEX EDUCATION LEARNING MEDIA MODULE TO IMPROVE KNOWLEDGE OF SEXUAL EDUCATION FOR MILD MENTALLY RETARDATED CHILDREN AT SLB HARAPAN MULIA JAMBI CITY}

\author{
${ }^{1}$ Erna Yulianti \\ ${ }^{2}$ Dessy Pramudiani \\ ${ }^{12}$ Departement of Psychology, Jambi University/work.yuliern@gmail.com
}

\begin{abstract}
Introduction Mild mentally retarded children experience sexual development like normal individuals. In principle, the material for sexual education taught is the same as for normal children with the presentation of material that is adjusted to the condition of the child's intelligence level and age. This module to facilitate children with mild mental retardation in learning knowledge of sexual education needs to be stimulated using 4 stages in the Busy Box Sex Education module.
\end{abstract}

Method This study aims to test the validity of the Busy Box Sex Education module to increase sexual knowledge of children with mild mental retardation. The type of research used is module validation research. This study used 4 validators who were determined based on a purposive technique to test the suitability of the module content with the objectives to be achieved. Data analysis used descriptive analysis using Aiken's $V$ (validation sheet).

Results The aiken's $V$ score showed a range of $0.56-0.88$ and the results of the validation of the aiken's V score of 0.50 - 0.88. Based on the validity test, the contents of the Busy Box Sex Education module were considered valid by the validator criteria with several suggestions for improvement.

Conclusion And Recommendation Based on the results of the module content validity test, it can be concluded that the Busy Box Sex Education module is at a good validity level.

Keywords: Module Validity, Sexual Education, Busy Box Sex Education.

\begin{abstract}
ABSTRAK
Pendahuluan Anak tunagrahita ringan mengalami perkembangan seksual seperti individu normal. Materi pendidikan seksual yang diajarkan pada prinsipnya sama seperti anak normal dengan penyajian materi yang disesuaikan dengan kondisi tingkat kecerdasan dan usia anak. Untuk memfasilitasi anak tunagrahita ringan dalam mempelajari pengetahuan pendidikan seksual perlu distimulasi menggunakan 4 tahapan dalam modul busy box sex education.

Metode Penelitian ini bertujuan untuk menguji validitas modul busy box sex education untuk meningkatkan pengetahuan seksual anak tunagrahita ringan. Jenis penelitian yang digunakan yaitu riset validasi modul. Penelitian ini menggunakan 4 orang validator yang ditentukan berdasarkan teknik purposive untuk menguji kesesuaian isi modul dengan tujuan yang hendak
\end{abstract}


dicapai. Analisis data menggunakan analisis deskriptif dengan menggunakan Aiken's V (lembar validasi).

Hasil Angka skor aiken's V menunjukkan rentang 0.56 - 0.88 dan hasil validasi alat ukur skor aiken's V $0.50-0.88$. Berdasarkan hasil uji validitas isi modul busy box sex education yang dinilai validator termasuk dalam kriteria valid dengan beberapa saran perbaikan.

Kesimpulan dan Saran Berdasarkan hasil uji validitas isi modul dapat disimpulkan bahwa modul busy box sex education berada pada tingkat validitas yang baik..

Kata Kunci: Validitas Modul, Pendidikan Seksual, Busy Box Sex Education

\section{Pendahuluan}

Pelecehan seksual bisa terjadi pada siapa saja termasuk anak berkebutuhan khusus. Minimnya pengetahuan pendidikan seksual bagi anak berkebutuhan khusus membuat sebagian diantara mereka cenderung mudah dimanipulasi oleh pelaku pelecehan seksual, sehingga mereka sering dijadikan objek pelampiasan seksual (Aziz, 2015).

Kasus-kasus kekerasan seksual pada anak berkebutuhan khusus atau disabilitas ini telah banyak terjadi. Menurut data yang disajikan dalam catatan tahunan (CATAHU) Komnas Perempuan Indonesia
(2019) kekerasan yang paling banyak ditemukan pada anak berkebutuhan khusus adalah kekerasan seksual sebanyak 64\% terutama pada anak perempuan. Jenis kekerasan seksual yang mendominasi terjadi dalam berbagai jenis yaitu pemerkosaan sebanyak 35 kasus, pelecehan seksual sebanyak 2 kasus, pencabulan sebanyak 9 kasus, persetubuhan sebanyak 10 kasus dan percobaan sebanyak 1 kasus.

Kekerasan seksual pada anak berkebutuhan khusus juga terdapat di Provinsi Jambi berdasarkan data yang didapat dari Dirreksrimum Polda Jambi dijabarkan pada tabel 1 berikut ini:

Tabel 1: Jumlah Korban Kekerasan dan Pelecehan Seksual pada ABK di Provinsi Jambi

\begin{tabular}{|c|c|c|c|c|c|c|c|c|c|}
\hline \multirow[t]{2}{*}{ No. } & \multirow[t]{2}{*}{ Kesatuan } & \multicolumn{2}{|c|}{ Jenis Kelamin } & \multicolumn{6}{|c|}{ Jumlah Korban (per Tahun) } \\
\hline & & $\mathbf{L}$ & $\mathbf{P}$ & 2015 & 2016 & 2017 & 2018 & 2019 & 2020 \\
\hline 1 & Ditreskrimum & - & - & - & - & - & - & - & - \\
\hline 2 & Polresta Jambi & - & 2 & - & - & - & 1 & - & 1 \\
\hline 3 & Polres Batanghari & - & - & - & - & - & - & - & - \\
\hline 4 & Polres Muaro Jambi & 9 & 1 & 2 & - & - & - & - & - \\
\hline 5 & $\begin{array}{l}\text { Polres Tanjung Jabung } \\
\text { Barat }\end{array}$ & - & - & 1 & - & - & - & - & - \\
\hline 6 & $\begin{array}{l}\text { Polres Tanjung Jabung } \\
\text { Timur }\end{array}$ & 1 & 1 & - & - & 1 & - & 1 & - \\
\hline 7 & Polres Bungo & - & - & - & - & - & - & - & - \\
\hline 8 & Polres Tebo & - & 1 & - & - & - & 1 & - & - \\
\hline 9 & Polres Merangin & - & 1 & - & - & - & - & - & 1 \\
\hline 10 & Polres Sarolangun & - & - & - & - & - & - & 1 & - \\
\hline 11 & Polres Kerinci & - & - & - & - & - & - & - & - \\
\hline \multicolumn{2}{|c|}{ JUMLAH } & 10 & 6 & 3 & - & 1 & 2 & 1 & 2 \\
\hline
\end{tabular}

Sumber: Dirreskrimum Polda Jambi (Februari, 2020)

Kasus kekerasan seksual yang terlapor dapat dikatakan seperti fenomena gunung es. Hal ini menandakan bahwa angka kasus pelaporan kekerasan seksual yang terjadi pada anak berkebutuhan khusus hanya terlihat sebagian saja dari kasus-kasus kekerasan yang ril terjadi di lapangan (Ningsih \& Hennyati, 2018). Hal ini didukung oleh pernyataan dari Komnas Perempuan (2019) dari laporan lembaga layanan banyak kasus kekerasan seksual yang sulit diproses secara hukum karena masih lemahnya kepedulian masyarakat terhadap individu berkebutuhan khusus 
dan minimnya pemahaman tentang disabilitas di kalangan aparat penegak hukum dan pemerintah. Beberapa lembaga layanan melaporkan bahwa seringkali kasus-kasus terhenti karena kurangnya alat bukti, tidak adanya saksi dan keterangan saksi korban dianggap tidak cukup meyakinkan. Minimnya penerjemah yang memahami bahasa isyarat juga menjadi kendala tersendiri dalam penanganan kasus.
Kasus pelecehan seksual pada korban disabilitas atau anak berkebutuhan khusus berdasarkan data yang didapatkan dari HWDI (Himpunan Wanita Disabilitas Indonesia) di Provinsi Jambi yang memberikan pendampingan korban pelecehan seksual pada individu penyandang disabilitas. Berikut ini data kasus yang terkumpul dari tahun 2016 2020 ditunjukkan pada tabel 2 berikut ini:

Tabel 2: Kasus Korban Kekerasan dan Pelecehan Seksual pada ABK di Provinsi Jambi

\begin{tabular}{|c|c|c|c|c|c|c|c|}
\hline No. & Tahun & $\begin{array}{c}\text { Bentuk } \\
\text { kekerasan }\end{array}$ & $\begin{array}{l}\text { Jumlah } \\
\text { korban }\end{array}$ & $\begin{array}{c}\text { Jenis } \\
\text { hambatan } \\
\text { korban }\end{array}$ & $\begin{array}{l}\text { Tempat } \\
\text { kejadian }\end{array}$ & $\begin{array}{c}\text { Hubungan } \\
\text { korban } \\
\text { dengan } \\
\text { pelaku }\end{array}$ & $\begin{array}{c}\text { Pendidikan } \\
\text { korban }\end{array}$ \\
\hline 1 & 2016 & Pemerkosaan & 1 & Tuli & Kebun & Tetangga & Tidak Sekolah \\
\hline 2 & 2016 & $\begin{array}{l}\text { Sodomi (Laki- } \\
\text { laki) }\end{array}$ & 9 & 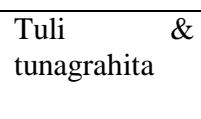 & Sekolah & Guru & $\begin{array}{l}\text { SDLB, } \\
\text { SMPLB, } \\
\text { SMALB }\end{array}$ \\
\hline 3 & 2018 & Pemerkosaan & 1 & Tuli & Hotel & $\begin{array}{l}\text { Teman dari } \\
\text { orang tua }\end{array}$ & SD \\
\hline 4 & 2019 & Pemerkosaan & 1 & Tuli & $\begin{array}{l}\text { Rumah } \\
\text { Korban }\end{array}$ & Tetangga & Tidak Sekolah \\
\hline 5 & 2020 & Pemerkosaan & 1 & Tunagrahita & $\begin{array}{l}\text { Rumah } \\
\text { Korban }\end{array}$ & $\begin{array}{l}\text { Ayah } \\
\text { Kandung }\end{array}$ & SD \\
\hline
\end{tabular}

Sumber: HWDI Provinsi Jambi (2020)

Korban pelecehan dan kekerasan seksual merasa malu karena dianggap hal tersebut menjadi sebuah aib yang harus disembunyikan, lalu jika pelaku adalah keluarganya sendiri atau korban merasa takut akan ancaman yang diberikan oleh pelaku (Ningsih \& Hennyati, 2018).

Kekerasan dan pelecehan seksual dilakukan dengan ancaman oleh pelaku, sehingga korban menjadi tidak berdaya. Kondisi tersebut menyebabkan korban menjadi terdominasi dan mengalami kesulitan untuk mengungkapkan dan melaporkan kasus yang telah terjadi. Pada anak berkebutuhan khusus, ancaman dianggap sebagai suatu hal yang serius dan menakutkan. Namun tidak sedikit pelaku kekerasan seksual ini melakukan aksinya tanpa kekerasan. Pelaku menggunakan manipulasi seperti menipu anak sehingga anak tersebut mengikuti keinginannya. Anak berkebutuhan khusus dengan hambatan yang dimilikinya kurang mampu menilai sesuatu sebagai tipu daya atau tidak (Noviana, 2015).

Salah satu korban yang menjadi objek kekerasan seksual pada anak berkebutuhan khusus adalah anak dengan hambatan tunagrahita ringan. Anak tunagrahita ringan adalah suatu kondisi anak yang memiliki kecerdasan (IQ) di bawah rata-rata $(70-50)$ dan ditandai dengan keterbatasan intelegensi dan ketidakcakapan dalam komunikasi sosial. (Rahmawati, 2014).

Jumlah anak tunagrahita diperkirakan 2,5-3\% dari jumlah populasi umumnya. Sesuai dengan karakteristiknya, kira-kira $85 \%$ anak-anak yang termasuk tunagrahita ringan dari populasi tunagrahita yang ada. Anak-anak ini dapat diajari akademik kirakira sampai kelas 4, 5 dan 6. Mereka dapat menjadi anak yang memiliki kepercayaan diri, mandiri, berkomunikasi dan 
berinteraksi sosial dengan baik apabila lingkungan sosialnya memberikan dukungan (Suharmini, dalam Wati, 2012).

Anak tunagrahita kurang memiliki pengetahuan tentang pendidikan seksual dikarenakan pelayanan dan pendidikan untuk anak tunagrahita yang mengarah pada pendidikan seksual juga masih belum mendapatkan perhatian secara khusus (Praptiningrum, 2006). Pendidikan seksual merupakan hal yang penting sebagai pendidikan bagi anak yang dapat membantu mereka menghadapi berbagai permasalahan yang bersumber dari dorongan seksual.

Pendidikan seksual merupakan bagian penting bagi perkembangan setiap individu. Ada banyak tantangan dalam menyediakan pendidikan seksual yang efektif dan tepat untuk anak dengan hambatan tunagrahita, kurangnya tenaga pengajar di sekolah dan kurangnya media yang tepat untuk dijadikan bahan ajar pendidikan seksual kepada anak tunagrahita (McDaniels \& Fleming, 2016).

Upaya yang dapat dilakukan dalam menangani perilaku seksual pada anak tunagrahita secara verbal dengan menasehatinya, mengingatkan dan memberikan intruksi pada saat anak sedang melakukan perilaku seksual dengan menggunakan bahasa yang mudah dimengerti anak runagrahita. Secara non verbal dalam menangani perilaku dengan mengadakan pembelajaran tambahan tentang kesehatan reproduksi dan memberikan hukuman atau punishment sebagai pengalihan aktivitas fungsional. (Taufan dkk, 2018).

Berdasarkan observasi awal tanggal 29 Agustus 2019 pada siswa tunagrahita kelas 5 SDLB Harapan Mulia Kota Jambi, pengetahuan pendidikan seksual dirasa masih kurang dan perlu ditingkatkan lagi. Dari hasil observasi terhadap 3 orang siswa (2 perempuan dan 1 laki-laki) belum mengetahui bagian tubuh apa saja yang tidak boleh disentuh orang lain orang lain. 3 siswa tersebut masih di arahkan untuk menyebutkan bagian dada, perut, alat kelamin (vagina/penis), pantat dan paha.
Khususnya pada bagian alat kelamin (vagina/penis), mereka tidak mengetahui nama alat alat kelamin yang dimilikinya. Untuk sentuhan yang boleh dilakukan pada bagian tubuh (kepala, tangan dan kaki) 2 orang siswa dapat mengidentifikasi namun masih sedikit diarahkan oleh fasilitator dan 1 orang siswa memberikan identifikasi yang kurang konsisten dan lebih banyak diarahkan oleh observer. Kemudian sentuhan yang harus dihindari atau tidak boleh sembarang mencium orang lain (bagian tubuh pipi dan mulut), ketiga siswa tersebut juga memberikan respon yang kurang konsisten sehingga perlu arahan jawaban oleh observer.

Permasalahan timbul karena kurangnya pengetahuan tentang pendidikan seksual pada anak tunagrahita. Anak tunagrahita belum terlalu memiliki pengetahuan tentang mengenali anggota tubuh beserta fungsinya, menanamkan budaya untuk mempunyai rasa malu, sentuhan boleh dan sentuhan tidak boleh, toilet training, menjaga kebersihan tubuh, kesopanan dan sosial circle serta menjaga pergaulan antar lain jenis kelamin (Chomaria, 2012).

Menurut Dewi (2016) permasalahan pendidikan seksual anak tunagrahita terletak pada pemahaman anak tunagrahita terhadap apa yang dialaminya dalam masa pubertas tidak sesuai dengan usia mentalnya. Anak tunagrahita memerlukan bantuan yang lebih dalam memahami perubahan yang terjadi pada dirinya. Memberikan bantuan pemahaman mengenai perubahan yang terjadi pada anak tunagrahita terkait perkembangan seksualnya di sekolah dapat disampaikan melalui media untuk memudahkan anak dalam menerima informasi pengetahuan pendidikan seksual.

Pendidikan seksual sebaiknya mampu membantu anak tunagrahita untuk mempersiapkan diri menjadi individu dewasa yang mandiri nantinya. Hasrat seksual adalah suatu hal yang bersifat alamiah. Masa pubertas yang terjadi pada anak berkebutuhan khusus biasanya terjadi 
lebih awal dari anak normal, namun bisa juga datang lebih lama atau mengalami keterlamabatan (Chomaria, 2012).

Pada anak tunagrahita, sebagian besar perkembangan psikoseksualnya tidak sesuai dengan tahapan usianya (Winarsih dkk, 2016). Walaupun kondisi mentalnya berada dibawah normal. Tetapi untuk perkembangan fisik seksualnya berkembang secara normal (Praptiningrum, 2006). Pendidikan seksual juga harus diajarkan pada anak tunagrahita sedini mungkin karena tanpa disadari anak-anak tersebut juga akan mengalami hal yang sama dengan anak normal lainnya. Sedangkan pada anak berkebutuhan khusus terkadang memiliki kadar mental dan emosional yang tidak stabil sehingga harus diajarkan secara bertahap (Chomaria, 2012).

Merujuk pada beberapa fakta dan literatur maka peneliti mengajukan sebuah media pembelajaran busy box sex education untuk memberikan pengetahuan pendidikan seksual pada anak tunagrahita ringan. Media penelitian ini dirancang untuk memberikan pengetahuan pendidikan seksual pada anak tunagrahita ringan dalam kategori mampu didik yang berusia $7-16$ tahun. Hal ini dikarenakan bahwa modul yang akan digunakan dalam penelitian ini merupakan media yang bersifat pembelajaran. Kategori usia ini ditetapkan berdasarkan usia perkembangan anak (Hurlock, 1994) dan teori perkembangan seksual Sigmund Freud dalam Desmita (2015). Dalam Hurlock (1994) usia 7-16 tahun merupakan usia anak-anak akhir dan usia masa sekolah, sehingga tepat untuk diberikan materi pembelajaran pengetahuan pendidikan seksual.

Pada rentang usia 7 - 16 tahun anak tunagrahita ringan akan memasuki masamasa pubertas dan modul ini diberikan agar anak memiliki pengetahuan tentang pendidikan seksual. Pendidikan seksual ini difokuskan pada materi identifikasi anggota tubuh, menanamkan rasa malu, sentuhan boleh dan sentuhan tidak boleh, toilet training, kebersihan tubuh, kesopanan dan social circle serta menjaga pergaulan antar lain jenis kelamin (Chomaria, 2012).

Kelemahan tingkat kecerdasan anak tunagrahita ringan dalam mengingat suatu hal-hal yang baru mereka temui, maka dibutuhkan media pembelajaran yang menarik untuk anak dengan harapan anak tersebut mudah untuk mengerti dan menyerap ilmu pengetahuan tentang materi pendidikan seksual menggunakan media busy box sex education (BSE).

Menurut Kuswanto \& Radiansyah (2018) media pembelajaran merupakan sarana agar peserta didik tidak merasa bosan dalam mengikuti pembelajaran dan efek yang diharapkan adalah media pembelajaran dapat memotivasi dan memudahkan peserta didik dalam menerima materi pembelajaran. Media busy box sex education juga terdapat beberapa media permainan yang dapat dimainkan oleh subjek/anak. Media permainan permainan edukatif memiliki keunggulan dengan desain visual yang menarik perhatian anak (Vitianingsih, 2016). Pada permainan edukatif mengajarkan suatu konsep pembelajaran pada anak secara efektif dan menyenangkan (Astini, 2017).

Media pembelajaran busy box sex eduation dilakukan secara demonstrasi dan bermain. Setiap anak didampingi oleh 1 fasilitator dan 1 observer dan diperagakan sesuai dengan intruksi fasilitator. Media ini terdiri dari 4 tahapan disesuaikan dengan komponen pendidikan seksual dalam Walker-Hirsch (2007). Tahap pertama yaitu Tahap Tubuhku yang terdiri dari stiker puzzle sederhana poster tubuhku dan bertujuan untuk mengenalkan bagian tubuh anak agar dapat mengidentifikasi bagian tubuh dan mengetahui fungsinya.

Tahap kedua yaitu Tahap Tutupi Aku. Tahapan ini terdiri dari boneka karakter aku, miniatur pakaian terbuka dan tertutup, beberapa miniatur karakter manusia, dan poster taman diperagakan sesuai dengan jenis kelamin anak. Tujuan dari tahap ini adalah menanamkan rasa malu kepada anak, memberi pengetahuan siapa saja yang boleh menyentuh bagian 
tubuh pribadinya dan memberikan pengetahuan upaya perlindungan diri.

Tahapan ketiga merupakan Tahap Sentuhan yang terdiri dari papan poster magnet dan magnet kode sentuhan. Tahap ini memiliki tujuan untuk memberi pengetahuan kepada anak terkait sentuhan yang harus dihindari, sentuhan yang boleh dan tidak boleh untuk dilakukan.

Tahap keempat adalah Tahap Seharusnya Aku yang bertujuan untuk memberikan pengetahuan tentang toileting dan mandi yang benar kepada anak untuk perawatan diri agar anak mampu melakukannya secara mandiri. Alat peraga yang digunakan dalam tahapan ini yaitu poster kamar mandi, boneka karakter aku, miniatur yang berkaitan (baju ganti, handuk, sisir, sabun dan sikat gigi). Setiap pertemuan mempelajari hanya 1 tahapan sebanyak 3 kali pertemuan dalam 1 minggu. Kemudian dilanjutkan dengan tahapan selanjutnya.

Berdasarkan uraian di atas, peneliti tertarik untuk melakukan penelitian mengenai uji validitas isi modul media pembelajaran busy box sex education untuk meningkatkan pengetahuan pendidikan seksual pada anak tunagrahita ringan di SLB Harapan Mulia Kota Jambi.

\section{Metode}

Metode yang digunakan dalam penelitian ini yaitu studi deskriptif dengan model 3D (define, design, develop), analisis data menggunakan rumus Aiken's V. Data penelitian dari tiga tahapan diantaranya yaitu define merupakan analisa kebutuhan pengetahuan pendidikan seksual di SLB Harapan Mulia Kota Jambi.
Tahapan design yaitu merancang metode dan langkah-langkah pelaksanaan program yang akan digunakan. Tahapan develop yaitu melakukan validasi oleh validator yang sekaligus menjadi expert judgment. Penetapan validator dilakukan secara purposive. Proses validasi yang dilakukan adalah validasi isi yaitu apakah modul yang telah dirancang sesuai kebutuhan pengetahuan pendidikan seksual.

Adapun kriteria validator penelitian uji validitas modul ini yaitu sebagai berikut: Pertama, Psikolog Klinis. Terdaftar sebagai anggota HIMPSI, memiliki Surat Izin Praktik Psikolog (SIPP), Surat Izin Praktik Psikolog Klinis (SIPPK). Kedua, Guru. Lulusan Sarjana Pendidikan Luar Biasa, guru di SLB Harapan Mulia Kota Jambi. Ketiga, Pengurus HWDI (Himpunan Wanita Disabilitas Indonesia). Tergabung dalam keanggotaan HWDI, pernah mengikuti workshop atau pelatihan pendampingan korban kekerasan seksual, dan berpengalaman mendampingi korban kasus kekerasan seksual pada anak berkebutuhan khusus. Keempat, Psikolog UPTD PPA Kota Jambi. Terdaftar sebagai anggota HIMPSI, memiliki Surat Izin Praktik Psikolog (SIPP), Surat Tugas menjadi Validator dari UPTD PPA Kota Jambi, memiliki pengalaman bekerja di UPTD PPA Kota Jambi minimal selama 1 tahun, menangani kasus kekerasan atau pelecehan seksual anak berkebutuhan khusus.

\section{Hasil}

Hasil validasi isi modul dan alat ukur yang digunakan dalam penelitian ini akan peneliti jelaskan berdasarkan tabel 4 di bawah ini: 
Uji Validitas Modul Media Pembelajaran

Busy Box Sex Education untuk Meningkatkan Pengetahuan Pendidikan Seksual di SLB

Harapan Mulia Kota Jambi

Tabel 4. Hasil Validasi Isi Modul

\begin{tabular}{|c|c|c|c|c|c|c|c|c|c|c|c|c|c|c|c|}
\hline \multirow{2}{*}{$\begin{array}{l}\text { Subbagian } \\
\text { Kegiatan }\end{array}$} & \multirow{2}{*}{$\begin{array}{c}\text { No. } \\
\text { Kegiatan }\end{array}$} & \multicolumn{8}{|c|}{ Skor } & \multirow{2}{*}{$\begin{array}{l}\text { Total } \\
\text { Nilai }\end{array}$} & \multirow[t]{2}{*}{$\sum \mathbf{s}$} & \multirow[t]{2}{*}{$\mathbf{N}$} & \multirow[t]{2}{*}{$c-1$} & \multirow{2}{*}{$\begin{array}{l}\text { Koefisien } \\
\text { Aiken's V }\end{array}$} & \multirow[t]{2}{*}{ Kategori } \\
\hline & & P1 & $\mathbf{S}$ & $\mathbf{P 2}$ & $\mathbf{S}$ & P3 & $\mathbf{S}$ & P4 & $\mathbf{S}$ & & & & & & \\
\hline \multirow[t]{4}{*}{ Tahap 1} & 1 & 4 & 3 & 4 & 3 & 4 & 3 & 4 & 3 & 16 & 12 & 4 & 4 & 0.75 & Tinggi \\
\hline & 2 & 4 & 3 & 4 & 3 & 4 & 3 & 5 & 4 & 17 & 13 & 4 & 4 & 0.81 & Sangat Tinggi \\
\hline & 3 & 4 & 3 & 3 & 2 & 4 & 3 & 2 & 1 & 13 & 9 & 4 & 4 & 0.56 & Cukup \\
\hline & 4 & 4 & 3 & 3 & 2 & 4 & 3 & 3 & 2 & 14 & 10 & 4 & 4 & 0.63 & Tinggi \\
\hline \multirow[t]{8}{*}{ Tahap 2} & 5 & 4 & 3 & 4 & 3 & 5 & 4 & 5 & 4 & 18 & 14 & 4 & 4 & 0.88 & Sangat Tinggi \\
\hline & 6 & 4 & 3 & 4 & 3 & 4 & 3 & 4 & 3 & 16 & 12 & 4 & 4 & 0.75 & Tinggi \\
\hline & 7 & 4 & 3 & 3 & 2 & 4 & 3 & 4 & 3 & 15 & 11 & 4 & 4 & 0.69 & Tinggi \\
\hline & 8 & 4 & 3 & 3 & 2 & 5 & 4 & 4 & 3 & 16 & 12 & 4 & 4 & 0.75 & Tinggi \\
\hline & 9 & 4 & 3 & 4 & 3 & 4 & 3 & 4 & 3 & 16 & 12 & 4 & 4 & 0.75 & Tinggi \\
\hline & 10 & 4 & 3 & 4 & 3 & 3 & 2 & 5 & 4 & 16 & 12 & 4 & 4 & 0.75 & Tinggi \\
\hline & 11 & 4 & 3 & 3 & 2 & 3 & 2 & 5 & 4 & 15 & 11 & 4 & 4 & 0.69 & Tinggi \\
\hline & 12 & 4 & 3 & 3 & 2 & 3 & 2 & 5 & 4 & 15 & 11 & 4 & 4 & 0.69 & Tinggi \\
\hline \multirow[t]{4}{*}{ Tahap 3} & 13 & 4 & 3 & 4 & 3 & 4 & 3 & 3 & 2 & 15 & 11 & 4 & 4 & 0.69 & Tinggi \\
\hline & 14 & 4 & 3 & 3 & 2 & 4 & 3 & 4 & 3 & 15 & 11 & 4 & 4 & 0.69 & Tinggi \\
\hline & 15 & 4 & 3 & 3 & 2 & 4 & 3 & 4 & 3 & 15 & 11 & 4 & 4 & 0.69 & Tinggi \\
\hline & 16 & 4 & 3 & 3 & 2 & 4 & 3 & 4 & 3 & 15 & 11 & 4 & 4 & 0.69 & Tinggi \\
\hline \multirow[t]{4}{*}{ Tahap 4} & 17 & 4 & 3 & 4 & 3 & 4 & 3 & 5 & 4 & 17 & 13 & 4 & 4 & 0.81 & Sangat Tinggi \\
\hline & 18 & 4 & 3 & 4 & 3 & 4 & 3 & 5 & 4 & 17 & 13 & 4 & 4 & 0.81 & Sangat Tinggi \\
\hline & 19 & 4 & 3 & 3 & 2 & 4 & 3 & 5 & 4 & 16 & 12 & 4 & 4 & 0.75 & Tinggi \\
\hline & 20 & 4 & 3 & 3 & 2 & 4 & 3 & 4 & 3 & 15 & 11 & 4 & 4 & 0.69 & Tinggi \\
\hline
\end{tabular}

Menurut Azwar (2018), rentang angka V yang dapat diperoleh adalah 01.00. Setiap skor V yang melebihi angka 0.50 dapat dianggap sebagai indikasi adanya validitas isi modul yang baik. Dalam tabel 4 skor angka yang ditampilkan dapat diinterpretasikan sebagai koefisien yang tinggi. Merujuk pada norma kriteria tingkat validasi modul menurut Azwar dalam Mardiya (2017) Skor V yang ditunjukkan berada dalam rentang angka 0.56 - 0.88 dengan kategori cukup - sangat tinggi. Angka rata-rata (mean) dari seluruh koefisien V subbagian sebesar 0.73. 
Tabel 4. Hasil Validasi Isi Alat Ukur

\begin{tabular}{|c|c|c|c|c|c|c|c|c|c|c|c|c|c|c|c|}
\hline \multirow[t]{2}{*}{ Tahap } & \multirow{2}{*}{$\begin{array}{l}\text { No } \\
\text { Item }\end{array}$} & \multicolumn{8}{|c|}{ Skor } & \multirow{2}{*}{$\begin{array}{l}\text { Total } \\
\text { Nilai }\end{array}$} & \multirow[t]{2}{*}{$\sum \mathbf{s}$} & \multirow[t]{2}{*}{$\mathbf{N}$} & \multirow[t]{2}{*}{ c-1 } & \multirow{2}{*}{$\begin{array}{l}\text { Koefisien } \\
\text { Aiken's V }\end{array}$} & \multirow[t]{2}{*}{ Kategori } \\
\hline & & P1 & $\mathbf{S}$ & P2 & $\mathbf{S}$ & P3 & $\mathbf{S}$ & P4 & $\mathbf{S}$ & & & & & & \\
\hline \multirow[t]{19}{*}{ Tahap 1} & 1 & 5 & 4 & 3 & 2 & 4 & 3 & 5 & 4 & 17 & 13 & 4 & 4 & 0.81 & Sangat Tinggi \\
\hline & 2 & 5 & 4 & 3 & 2 & 4 & 3 & 5 & 4 & 17 & 13 & 4 & 4 & 0.81 & Sangat Tinggi \\
\hline & 3 & 5 & 4 & 3 & 2 & 4 & 3 & 5 & 4 & 17 & 13 & 4 & 4 & 0.81 & Sangat Tinggi \\
\hline & 4 & 5 & 4 & 4 & 3 & 4 & 3 & 5 & 4 & 18 & 14 & 4 & 4 & 0.88 & Sangat Tinggi \\
\hline & 5 & 5 & 4 & 4 & 3 & 4 & 3 & 5 & 4 & 18 & 14 & 4 & 4 & 0.88 & Sangat Tinggi \\
\hline & 6 & 5 & 4 & 3 & 2 & 4 & 3 & 5 & 4 & 17 & 13 & 4 & 4 & 0.81 & Sangat Tinggi \\
\hline & 7 & 5 & 4 & 4 & 3 & 4 & 3 & 5 & 4 & 18 & 14 & 4 & 4 & 0.88 & Sangat Tinggi \\
\hline & 8 & 5 & 4 & 4 & 3 & 4 & 3 & 5 & 4 & 18 & 14 & 4 & 4 & 0.88 & Sangat Tinggi \\
\hline & 9 & 5 & 4 & 4 & 3 & 4 & 3 & 5 & 4 & 18 & 14 & 4 & 4 & 0.88 & Sangat Tinggi \\
\hline & 10 & 5 & 4 & 4 & 3 & 4 & 3 & 5 & 4 & 18 & 14 & 4 & 4 & 0.88 & Sangat Tinggi \\
\hline & 11 & 5 & 4 & 4 & 3 & 4 & 3 & 5 & 4 & 18 & 14 & 4 & 4 & 0.88 & Sangat Tinggi \\
\hline & 12 & 5 & 4 & 4 & 3 & 4 & 3 & 5 & 4 & 18 & 14 & 4 & 4 & 0.88 & Sangat Tinggi \\
\hline & 13 & 5 & 4 & 3 & 2 & 4 & 3 & 5 & 4 & 17 & 13 & 4 & 4 & 0.81 & Sangat Tinggi \\
\hline & 14 & 5 & 4 & 3 & 2 & 4 & 3 & 5 & 4 & 17 & 13 & 4 & 4 & 0.81 & Sangat Tinggi \\
\hline & 15 & 5 & 4 & 4 & 3 & 4 & 3 & 5 & 4 & 18 & 14 & 4 & 4 & 0.88 & Sangat Tinggi \\
\hline & 16 & 5 & 4 & 4 & 3 & 4 & 3 & 5 & 4 & 18 & 14 & 4 & 4 & 0.88 & Sangat Tinggi \\
\hline & 17 & 5 & 4 & 4 & 3 & 4 & 3 & 5 & 4 & 18 & 14 & 4 & 4 & 0.88 & Sangat Tinggi \\
\hline & 18 & 5 & 4 & 4 & 3 & 4 & 3 & 5 & 4 & 18 & 14 & 4 & 4 & 0.88 & Sangat Tinggi \\
\hline & 19 & 5 & 4 & 3 & 2 & 4 & 3 & 5 & 4 & 17 & 13 & 4 & 4 & 0.81 & Sangat Tinggi \\
\hline \multirow[t]{13}{*}{ Tahap 2} & 20 & 4 & 3 & 4 & 3 & 4 & 3 & 5 & 4 & 17 & 13 & 4 & 4 & 0.81 & Sangat Tinggi \\
\hline & 21 & 4 & 3 & 4 & 3 & 4 & 3 & 5 & 4 & 17 & 13 & 4 & 4 & 0.81 & Sangat Tinggi \\
\hline & 22 & 4 & 3 & 4 & 3 & 5 & 4 & 5 & 4 & 18 & 14 & 4 & 4 & 0.88 & Sangat Tinggi \\
\hline & 23 & 4 & 3 & 3 & 2 & 3 & 2 & 2 & 1 & 12 & 8 & 4 & 4 & 0.50 & Cukup \\
\hline & 24 & 4 & 3 & 4 & 3 & 4 & 3 & 3 & 2 & 15 & 11 & 4 & 4 & 0.69 & Tinggi \\
\hline & 25 & 4 & 3 & 4 & 3 & 4 & 3 & 3 & 2 & 15 & 11 & 4 & 4 & 0.69 & Tinggi \\
\hline & 26 & 4 & 3 & 4 & 3 & 4 & 3 & 2 & 1 & 14 & 10 & 4 & 4 & 0.63 & Tinggi \\
\hline & 27 & 4 & 3 & 4 & 3 & 4 & 3 & 3 & 2 & 15 & 11 & 4 & 4 & 0.69 & Tinggi \\
\hline & 28 & 4 & 3 & 4 & 3 & 4 & 3 & 5 & 4 & 17 & 13 & 4 & 4 & 0.81 & Sangat Tinggi \\
\hline & 29 & 4 & 3 & 4 & 3 & 4 & 3 & 4 & 3 & 16 & 12 & 4 & 4 & 0.75 & Tinggi \\
\hline & 30 & 5 & 4 & 4 & 3 & 4 & 3 & 5 & 4 & 18 & 14 & 4 & 4 & 0.88 & Sangat Tinggi \\
\hline & 31 & 5 & 4 & 4 & 3 & 4 & 3 & 4 & 3 & 17 & 13 & 4 & 4 & 0.81 & Sangat Tinggi \\
\hline & 32 & 5 & 4 & 4 & 3 & 4 & 3 & 5 & 4 & 18 & 14 & 4 & 4 & 0.88 & Sangat Tinggi \\
\hline \multirow[t]{4}{*}{ Tahap 3} & 33 & 5 & 4 & 3 & 2 & 4 & 3 & 4 & 3 & 16 & 12 & 4 & 4 & 0.75 & Tinggi \\
\hline & 34 & 5 & 4 & 3 & 2 & 4 & 3 & 4 & 3 & 16 & 12 & 4 & 4 & 0.75 & Tinggi \\
\hline & 35 & 5 & 4 & 3 & 2 & 4 & 3 & 5 & 4 & 17 & 13 & 4 & 4 & 0.81 & Sangat Tinggi \\
\hline & 36 & 5 & 4 & 4 & 3 & 4 & 3 & 4 & 3 & 17 & 13 & 4 & 4 & 0.81 & Sangat Tinggi \\
\hline
\end{tabular}


Uji Validitas Modul Media Pembelajaran

Busy Box Sex Education untuk Meningkatkan Pengetahuan Pendidikan Seksual di SLB

Harapan Mulia Kota Jambi

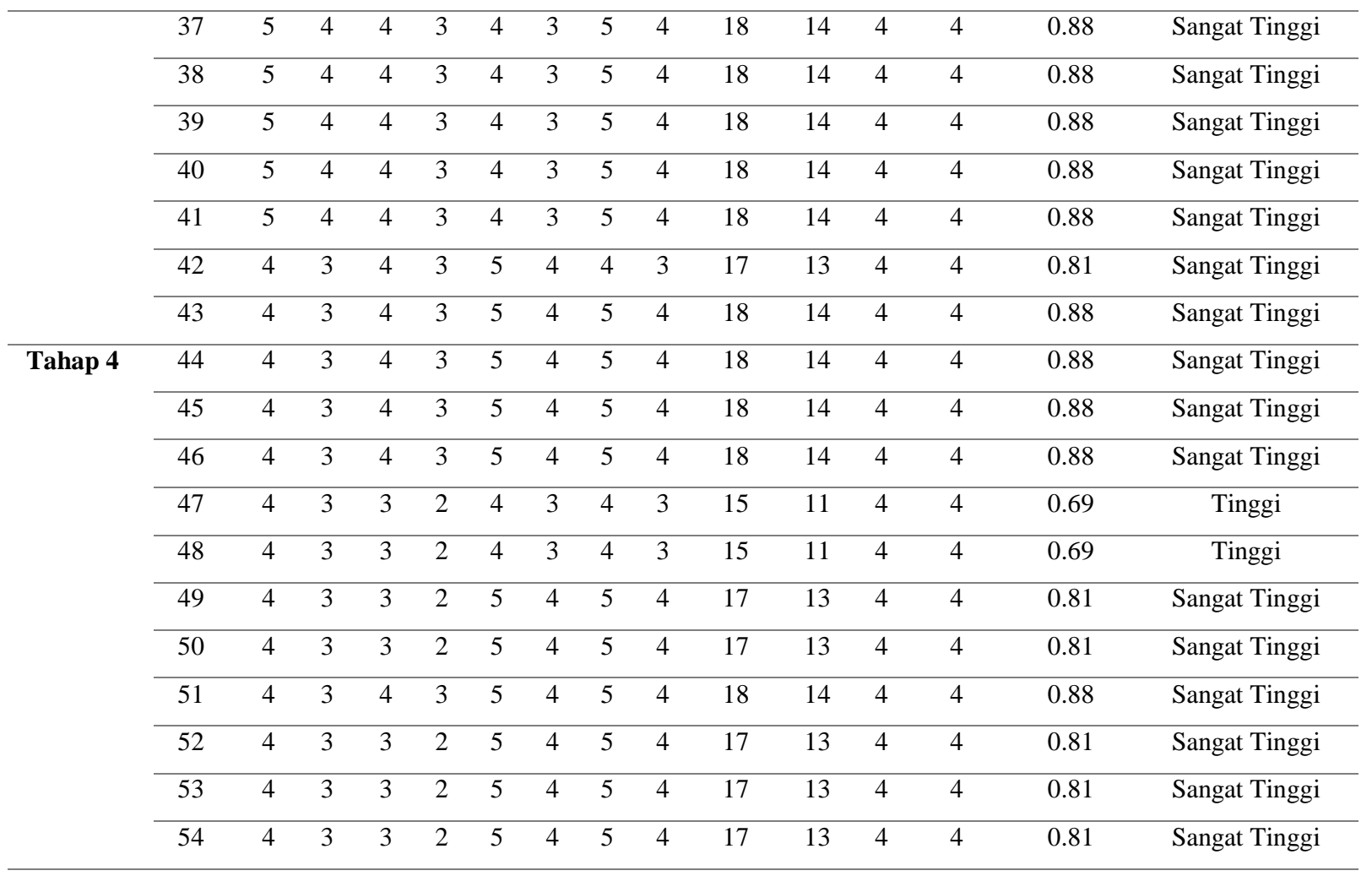

Dalam Sugiyono (2017) yang menjelaskan bahwa rentang angka $\mathrm{V}$ yang dapat diperoleh adalah $0-1.00$. setiap skor $\mathrm{V}$ yang melebihi angka 0.30 dapat disimpulkan bahwa butir instrumen tersebut dinyatakan valid. Skor angka yang ditampilkan tabel 4 dapat diinterpretasikan sebagai koefisien yang bergerak dari kategori cukup - sangat tinggi. Angka yang ditunjukkan dari data tabel skor $\mathrm{V}$ adalah $0.50-0.88$ sehingga menunjukkan semua butir instrumen alat ukur busy box sex education dinyatakan valid dengan rentang skor diatas 0.30 .

\section{Pembahasan}

Penelitian ini merupakan penelitian riset validasi modul yang dilakukan mengikuti prosedur pengembangan model 4D yang dikemukakan oleh Thiagarajan (1974). Model 4D diantaranya define, design, develop dan dissemination. Prosedur pengembangan dalam penelitian validasi modul ini dimodifikasi menjadi model 3D hanya sampai pada tahap uji coba terbatas (develop) dengan menggunakan studi deskriptif. Uji validasi isi modul dengan validator atau expert judgement menghasilkan modul yang dapat menjawab permasalahan penelitian dan siap untuk diuji coba di lapangan.

Permasalahan diangkat dari keterbatasan kemampuan kognitif anak tunagrahita ringan yang berada di bawah rata-rata untuk mempelajari pengetahuan pendidikan seksual. Mangunsong (2014) anak hambatan tunagrahita ringan yaitu anak yang memiliki hambatan intelektual serta memiliki IQ di bawah rata-rata dengan rentang 50 - 70. Anak memiliki hambatan pada beberapa aspek yaitu emosi-sosial, bahasa, kognitif dan penyesuaian diri. Anak juga memerlukan perhatian pada saat proses pembelajaran yang menyebabkan anak membutuhkan layanan khusus dan media untuk membantu proses pembelajaran pengetahuan pendidikan seksual.

Untuk menindaklanjuti permasalahan yang ada, maka peneliti merancang modul media pembelajaran busy box sex education sebagai stimulasi untuk mengingkatkan pengetahuan pendidikan seks anak 
tunagrahita ringan. Penyusunan modul dilakukan dengan menentukan kegiatan, merancang tahapan kegiatan pembelajaran yang disesuaikan dengan komponen pengetahuan pendidikan seksual untuk anak tunagrahita ringan, hingga merancang alat ukur penelitian.

Modul merupakan sebuah paket intruksi yang disesuaikan dengan kebutuhan peserta dalam menguasai suatu materi. Sebelum dapat digunakan, maka diperlukan uji validitas isi pada modul tersebut (Agustini \& Andayani, 2017). Modul Busy box sex education adalah media pembelajaran untuk memfasilitasi atau membantu dan memberi stimulus kepada anak tunagrahita ringan dalam meningkatkan pengetahuan pendidikan seksual. Uji validitas isi modul busy box sex education dinilai oleh 4 orang expert judgement.

Dari data aiken's V yang dilampirkan pada hasil penelitian, secara tidak langsung setiap langkah atau tahapan pada modul dan skala dapat menjadi stimulus kepada anak tunagrahita ringan dalam meningkatkan pengetahuan pendidikan seksual. Saran perbaikan yang diberikan validator terkait hal-hal yang perlu diperhatikan dan dikembangkan dalam modul ini digunakan untuk menyempurnakan modul agar lebih baik dan siap untuk diuji cobakan.

Penelitian ini menggunakan studi deskriptif dengan model 3D yang dikembangkan oleh Thiagarajan (1974) dan merujuk pada penelitian Ekawati \& Saputra (2018) diantaranya yaitu Define, Design, dan Develop. Pada tahapan Define, peneliti melakukan analisa kebutuhan untuk melihat gambaran permasalahan dilapangan mengenai pengetahuan pendidikan seksual melalui observasi kepada 3 orang anak tunagrahita di SLB Harapan Mulia Kota Jambi. Kemudian peneliti mengumpulkan data lapangan kekerasan seksual pada anak berkebutuhan khusus dan atau anak tunagrahita melalui wawancara untuk mendapatkan data awal dengan Guru SLB Harapan Mulia Kota Jambi, Ketua HWDI Provinsi Jambi dan kabid PPA Polda Jambi.
Dari analisis kebutuhan yang didapatkan, anak tunagrahita ringan di SLB Harapan Mulia Kota Jambi perlu diberikan pengetahuan pendidikan seksual.

Penelitian ini sejalan dengan penelitian Yuliani dan Armaini (2019) berjudul "efektivitas media video animasi dalam meningkatkan pengetahuan pendidikan seks anak dengan hambatan kecerdasan ringan di kelas V SLB Kemala Bhayangkari Kabupaten Tanah Datar".

Aziz (2015) menyatakan bahwa secara garis besar, materi pendidikan seksual untuk anak berkebutuhan khusus pada prinsipnya sama seperti anak normal. Namun secara khusus penyajian materi pendidikan seksual untuk anak berkebutuhan khusus lebih disesuaikan dengan kondisi fisik, psikologis dan tingkat usia anak.

Perubahan perilaku yang diharapkan setelah anak tunagrahita ringan mengikuti kegiatan ini sejalan dengan hasil penelitian Kusuma dan Widiani (2017) anak yang memiliki pengetahuan tentang seks dapat mencegah terjadinya dampak-dampak negatif yang tidak diharapkan.

Peneliti menyusun kegiatan dan modul berdasarkan analisis kebutuhan yang telah dilakukan pada tahap define. Media pembelajaran busy box sex education merupakan salah satu media pembelajaran atau alat peraga yang digunakan dalam memberikan pengetahuan mengenai materi pendidikan seksual secara bertahap kepada anak tunagrahita. Media ini bersifat interaktif dan dapat memunculkan rasa ingin tahu anak dan membuat anak tersebut tertarik mengikuti 4 tahapan aktivitas belajar sambil bermain pada alat peraga yang ada di dalam box atau kotak. Sejalan dengan penelitian yang dilakukan oleh Mufliharsi (2017), media yang digunakan yaitu media busy book merupakan media pembelajaran interaktif berisi aktivitas permainan sederhana yang mampu merangsang kemampuan motorik halus.

Modul media pembelajaran busy box sex education digunakan untuk menstimulasi anak tunagrahita ringan 
$\begin{array}{llr}\text { mempelajari } & \text { pengetahuan } & \text { pendidikan } \\ \text { seksual } & \text { dikarenakan } & \text { sistem }\end{array}$ pembelajarannya dilakukan secara bertahap. Hal ini sejalan dengan pernyataan Mumpuniarti (2007) dalam Suryani \& Mumpuniarti (2018), prinsip pembelajaran yang dilakukan kepada anak tunagrahita ringan diantaranya suatu program hendaknya disusun dari tahapan yang sederhana menuju yang lebih kompleks dan belajar dilakukan secara aktif. Evaluasi yang konsisten pada tiap pertemuan dilakukan agar memperoleh refleksi setiap materi pengajaran sehingga dapat memberikan catatan agar diperoleh cara yang efektif dan efisien.

Media busy box sex education diharapkan lebih mudah dipraktekkan pada saat uji coba dan penelitian yang dilaksanakan langsung kepada anak tunagrahita ringan. Bentuk penyajian modul media pembelajaran busy box sex education dilakukan melalui metode bermain dan demonstrasi atau praktik. Aziz (2015) menjelaskan bahwa metode bermain bertujuan untuk meningkatkan perkembangan intelegensi, fisik, emosi dan cara bersosialisasi setiap anak. Dalam media ini terdapat beberapa permainan yang harus dimainkan seperti menyusun puzzle sederhana Tubuhku. Seperti yang dijelaskan Kusnawan \& Lisnawati dalam Massuhartono \& Putri (2020), metode demonstrasi adalah suatu metode yang digunakan untuk memperlihatkan dan mencontohkan suatu proses atau cara kerja suatu benda yang berkaitan dengan bahan pelajaran. Fasilitator memberikan pengetahuan pendidikan seksual melalui media dan alat peraga yang disediakan didalam busy box sex education. Sejalan dengan penelitian Dewi, dkk (2016) yang meneliti terkait metode demonstrasi kepada anak tunagrahita didapatkan hasil bahwa metode demonstrasi berpengaruh terhadap berkarya seni rupa teknik kolase pada anak tunagrahita.

Untuk memaksimalkan tahapan Tubuhku dalam modul dan skala komponen physiology yang memuat pengetahuan tentang bagian tubuh beserta fungsinya, anak diberikan pengetahuan terkait penamaan asli dari bagian tubuh seperti nama alat kelamin (penis/vagina), anus dan payudara. Hal ini sejalan dengan pernyataan Setyowati, dkk (2017) yang mengatakan bahwa masalah pendidikan seksual adalah hal yang tabu. masih banyak orang tua yang merasa malu dan sungkan untuk mengajarkan beberapa nama anggota tubuh dengan nama aslinya kepada anak sehingga anak menjadi minim informasi seksualitas.

Media ini menggunakan alat peraga berupa puzzle sederhana Tubuhku. Puzzle tidak hanya sekedar merupakan permainan yang menyenangkan hati anak, namun puzzle juga dapat menjadi media pembelajaran anak. Pada penelitian sebelumnya yang dilakukan oleh Muflihah, dkk (2019), intervensi bermain dan belajar melalui permainan puzzle dapat meningkatkan pengetahuan terkait seksualitas kepada anak.

Pengoptimalan tahapan Tutupi Aku yang memuat pengetahuan menanamkan rasa mali, memberikan pengetahuan terkait siapa saja yang boleh menyentuh bagian tubuh pribadinya dan memberikan upaya perlindungan diri ketika dalam keadaan bahaya. Chomaria (2012) menyatakan bahwa tingkat kematangan anak berkebutuhan khusus biasanya terbelakang, hal ini yang menyebabkan anak berkebutuhan khusus tidak merasa malu jika tidak mengenakan pakaian di hadapan orang lain. Keterampilan perlindungan diri anak dari pelecehan seksual dapat dilihat dari bagaimana anak bersikap dan berkata.

Subbagian modul dan skala komponen social skill terkait upaya perlindungan diri disesuaikan dengan penelitian Wulandari, dkk (2016) yang menyatakan bahwa anak mampu menolak dengan baik secara verbal, menghindar keluar dari situasi yang membahayakan, memberitahu dan melaporkan kepada orang lain. Keterampilan menolak tindakan pelecehan seks secara verbal dapat melalui perkataan "tolong" dan "tidak mau". 
Soba dalam Afifah \& Chamidah (2018) mengatakan bahwa sentuhan pada bagian tubuh pribadi dapat menunjukkan 2 rasa sikap, yakni menghormati dan pelecehan. Sentuhan rasa hormat adalah sentuhan yang tidak melibatkan bagian tubuh pribadi. Ayah atau ibu akan menyentuh bagian tubuh pribadi anak ketika sedang membersihkan atau merawat bagian tubuh yang sedang cidera. Selain itu dokter juga akan menyentuh bagian tubuh pribadi anak ketika sedang memeriksa kesehatan anak dengan didampingi oleh orang tua dan tentunya atas izin anak.

Untuk mengoptimalkan perbaikan dalam tahapan ini pada modul dan skala mengenai siapa saja yang boleh dan tidak boleh menyentuh bagian tubuh pribadi sejalan dengan penelitian Sari \& Andriyani (2020) pada anak perempuan, yang hanya boleh menyentuh bagian tubuh pribadi adalah diri sendiri dan ibu atas persetujuan dari anak serta dokter yang mengobati ketika sakit atas persetujuan anak. Hal ini ditegaskan agar tidak terjadi kekerasan dan pelecehan seksual pada anak tunagrahaita ringan.

Dalam penelitian Marlina \& Pransiska (2018) mengemukakan bahwa pengetahuan seks diberikan kepada anak agar bisa terhindar dari tindakan kekerasan seksual. Penyusunan modul dan skala komponen relationship skill disesuaikan dengan penelitian Justicia (2016) mengenai program underwear rules yang memiliki aturan sederhana dimana anak tidak boleh disentuh oleh orang lain pada bagian tubuhnya yang ditutupi oleh pakaian dalam (underwear) anak dan tidak boleh menyentuh bagian tubuh orang lain yang ditutupi pakaian dalam. Pengetahuan batasan sentuhan bagian tubuh dari orang lain dapat meningkatkan kewaspadaan anak terhadap perilaku jahat dari orang di sekitar anak.

Pengoptimalkan tahapan seharusnya aku dan skala komponen personal care yang memuat pengetahuan mengenai kebersihan diri, toilet training agar mampu diterapkan dalam kehidupan sehari-harinya ini disesuaikan dengan pernyataan Welker dan Hirsch (2007) yang mengemukakan kegiatan perawatan diri mengacu pada berpakaian, toileting, mandi serta kebersihan lainnya dapat dilakukan secara berulang oleh anak tunagrahita ringan. Kemandirian dalam cukup penting dan dapat dilakukan agar individu dengan keterbatasan intelektual dapat berfungsi secara mandiri..

Russel dan Johanningsmier dalam Agustini dan Andayani (2017) menyatakan bahwa dalam proses penerapan modul terdapat hal-hal yang harus diperhatikan diantaranya; peran fasilitator, pengaturan pada modul, fasilitas dan peralatan yang digunakan, serta proses dalam penilaian atau observasi. Peran fasilitator dalam proses pelatihan antara lain mengajak subjek untuk terlibat dalam proses pembelajaran, membuat materi yang disampaikan menjadi menarik, menyusun intruksi yang akan disampaikan, serta mampu memahami kondisi dari subjek. Hal ini sejalan dengan penelitian Massuhartono dan Putri (2020) yang mengatakan peran fasilitator bertujuan untuk dapat menciptakan lingkungan kelas dan suasana belajar yang nyaman bagi peserta didik sehingga interaksi dalam proses belajar akan berlangsung secara efektif dan efisien.

Observasi yang akan dilakukan oleh observer pada setiap pertemuan diperkuat dengan pencatatan data anekdot secara verbatim agar data dapat diolah secara deskriptif dan untuk melihat kebutuhan subjek sebagai pembenahan pada tiap pertemuan. Sejalan dengan pernyataan Soesilo dan Padmomartono (2014) dengan catatan anekdot ini observer dapat mengetahui perilaku atau respon subjek yang ditimbulkan di luar aspek penilaian. Catatan anekdot merupakan catatan kejadian khusus yang berkaitan dengan suatu hal yang menjadi pusat perhatian observer terutama tingkah laku atau respon yang ditimbulkan oleh subjek pada saat proses penelitian berlangsung.

Bahasa yang digunakan pada modul busy box sex education dalam 
penyampaian materi menggunakan bahasa yang fleksibel namun tetap memiliki tujuan yang sesuai dengan isi modul yang akan diajarkan kepada anak. Dalam proses pembelajaran modul ini, diperbolehkan menggunakan improvisasi bahasa yang lebih sederhana namun tetap sesuai dengan tujuan pada modul agar anak dapat mengerti terkait materi pengetahuan pendidikan seksual yang telah di pelajari melalui modul busy box sex education. Febrisma (2020) menjelaskan bahwa anak tunagrahita memiliki kesulitan dalam hal atensi, daya ingat, bahasa dan akademik. Pada dasarnya perolehan bahasa pada anak tunagrahita sama seperti pada anak normal, yang membedakannya adalah kemampuan kecerdasan.

Waktu yang dibutuhkan dalam setiap pertemuan untuk melakukan proses pembelajaran tahapan busy box sex education menggunakan waktu selama 1 jam dan dilakukan secara efisien. Fasilitator bersikap untuk tanggap, melakukan komunikasi nonverbal berupa perhatian, gaya bicara, kualitas suara yang ditampilkan dalam membangun suasana belajar yang dapat dinikmati oleh subjek tunagrahita ringan agar subjek tidak merasa bosan dan tidak merasa tertekan dalam mengikuti proses pembelajaran.

Pemberian respon positif yang diberikan oleh fasilitator kepada subjek berupa penghargaan terhadap jawaban atau respon subjek. Penghargaan berupa pujian dan tepuk tangan dapat mendukung proses pembelajaran. Hal ini sejalan dengan penelitian yang dilakukan oleh Indrawati (2016) yang mengatakan bahwa manajemen kelas dalam mengajar anak tunagrahita dengan cara menggunakan waktu secara efisien dan bersikap tanggap dalam memberikan bantuan dan cara guru memberikan umpan balik yaitu memberikan penguatan berupa penghargaan, menciptakan suasana pembelajaran yang kondusif dengan cara mendorong anak tunagrahita untuk aktif dalam mengikuti pembelajaran.
Saran perbaikan yang diberikan oleh validator dalam penelitian ditindaklanjuti dengan melakukan revisi modul sehingga didapatkan produk akhir berupa modul media pembelajaran busy box sex education untuk meningkatkan pengetahuan pendidikan seksual yang telah memenuhi kriteria kelayakan berdasarkan hasil Aiken's V uji validitas isi modul. Dengan demikian modul ini diharapkan dapat membantu anak tunagrahita ringan dalam meningkatkan pengetahuan pendidikan seksual.

\section{Kesimpulan}

Berdasarkan penelitian yang dilakukan pada uji validitas isi modul Media Pembelajaran Busy box sex education untuk Meningkatkan Pengetahuan Pendidikan seksual Anak Tunagrahita Ringan di SLB Harapan Mulia Kota Jambi, maka kesimpulan dalam penelitian ini diantaranya; Adanya kesesuaian hasil skor uji validitas isi modul Busy box sex education (BSE). Hal ini dapat diartikan bahwa modul ini dinyatakan valid untuk meningkatkan pengetahuan pendidikan seksual anak tunagrahita ringan serta memiliki kelayakan untuk digunakan.

Hasil validitas isi modul yang dinilai oleh validator menunjukkan rentang angka skor V bergerak dari $0.56-0.88$. Subbagian modul dari media pembelajaran $B S E$ memiliki isi yang baik dengan rentang skor diatas 0.50. Rata-rata keseluruhan koefisien validitas isi modul $B S E$ sebesar 0.73 .

Hasil validasi alat ukur yang dinilai oleh validator menunjukkan rentang skor yang bergerak dari $0.50-0.88$. Alat ukur pengetahuan pendidikan seksual anak tunagrahita ringan dikategorikan valid dengan rentang skor diatas 0.30 .

\section{Saran}

Berdasarkan hasil penelitian yang telah dicapai serta mengingat masih banyaknya keterbatasan dalam penelitian ini, maka peneliti memberikan beberapa saran kepada pihak sekolah menjadi bahan pertimbangan untuk merancang 
program pembelajaran pada anak tunagrahita ringan sehingga dapat membantu meningkatkan pengetahuan pendidikan seksual dengan metode demonstrasi menggunakan media dan belajar sambil bermain. Bagi para guru untuk bisa mengaplikasikannya pengajaran pendidaikan seksual apada anak tunagrahita ringan dengan modul atau media pembelajaran busy box sex education. Sedangkan bagi peneliti Selanjutnya hasil dari penelitian ini diharapkan tidak terhenti sampai di uji validitas isi modul, perlu di uji coba untuk mengetahui kesesuaian hasil validasi modul dan skala pada media pembelajaran busy box sex education untuk meningkatkan pengetahuan pendidikan seksual anak tunagrahita ringan di SLB Harapan Mulia Kota Jambi dan dilakukan secara eksperimen.

\section{Daftar Pustaka}

Anjani, D. A., \& Nurjanah, S. (2014). Permainan Puzzle Mempengaruhi Perkembangan Kecerdasan VisualSpatial Anak Usia 4-5 Tahun Di Tk Al-Fath Desa Keboan Anom Gedangan Sidoarjo. Journal of Health Sciences, 7(2).

Azwar, S. (2018). Metode Penelitian Psikologi Edisi II. Yogyakarta: Pustaka Pelajar

Desmita. (2015). Psikologi Perkembangan. Bandung: PT Remaja Rosdakarya.

Ekawati, Y. N., \& Saputra, N. E. Uji Coba Modul Paket Alat Permainan Edukatif (Ape) Cengkling/Engklek Untuk Meningkatkan Visual Spasial Anak Usia Dini.

Elfiadi, E. (2017). Kecerdasan Jamak Pada AUD. Itqan: Jurnal Ilmu Kependidikan, 8(2), 35-52.

Fadilah. (2012). Teori belajar Konstruktivistik Vygotsky. Jurnal Psikologi Belajar Vol 1

Kemendikbud. (2019). Mendikbud: Pentingnya Konsep Bermain dan Belajar di Jenjang PAUD diakses dari https://www.kemdikbud.go.id. Pada 03 Desember 2019.

Kustiawan,Usep. (2016). Pengembangan Media Pembelajaran Anak Usia Dini. Malang: Gunung Samudera.

Luthfi, M. F. (2014). Pembelajaran Menggairahkan Dengan Ice Breaking. Madinah: Jurnal Studi Islam, 1(1), 27-29.

Marlisa, Lusi. (2016). Tuntutan Calistung Pada Anak Usia Dini. Jurnal ilmiah tumbuh kembang anak usia dini. Volume 1 no 3.

Pradnyawati, N. L. G. N., Antara, P. A., Ujianti, P. R., \& Psi, S. (2017). Pengaruh Ragam Hias Geometri Terhadap Kecerdasan Visual-Spasial Pada Anak Gugus V Kecamatan Kediri Kabupaten Tabanan. Jurnal Pendidikan Anak Usia Dini Undiksha, 5(1).

Pratiwi, W. (2017). Konsep bermain pada anak usia dini. TADBIR: Jurnal MPI, 5(2), 106-117.

Rahayu, Fuji.Y. (2014). Peningkatan Kemampuan Kognitif Anak Melalui Bermain Puzzle Di Kelompok B Tk Dharma Wanita Sidowarek II Plemahan-Kediri. Paud Teratai, 3(1).

Republik Indonesia, (2003). UndangUndang Republik Indonesia Nomor 20 Tahun 2003 Tentang Sistem Pendidikan Nasional. Retrieved from http://kelembagaan.ristekdikti.go.id/ wpcontent/uploads/2016/08/UU_no_ 0 th2003 .pdf

Rosidah, L. (2014). Peningkatan Kecerdasan Visual Spasial Anak Usia Dini Melalui Permainan Mazelaily Rosidah. Jurnal Pendidikan Usia Dini, 8(2), 291-300.

Susanto, Ahmad. (2017). Pendidikan Anak Usia Dini (Konsep dan Teori). Jakarta: Bumi Aksara. 
Busy Box Sex Education untuk Meningkatkan Pengetahuan Pendidikan Seksual di SLB Harapan Mulia Kota Jambi

Syamsuardi, S. (2012). Penggunaan Alat Permainan Edukatif (APE) Di Taman Kanak-Kanak Paud Polewali Kecamatan Tanete Riattang Barat Kabupaten Bone. Publikasi Pendidikan, 2(1).
Thiagarajan, S. (1974). Instructional Development For Training Teachers Of Exceptional Children: A Sourcebook 